\title{
Achieving a high share of non-hydro renewable integration in Brazil through wind power: regional growth and employment effects
}

Tiago Diniz ( $\nabla$ tiagotbd@gmail.com )

Eletrobras CHESF https://orcid.org/0000-0002-7458-2256

Lilia Couto

UCL https://orcid.org/0000-0003-4292-1265

\section{Short Report}

Keywords: wind power, renewable energy policy, Brazil, CGE

Posted Date: November 1st, 2021

DOI: https://doi.org/10.21203/rs.3.rs-1029217/v1

License: (c) (i) This work is licensed under a Creative Commons Attribution 4.0 International License.

Read Full License 


\begin{tabular}{|c|c|}
\hline 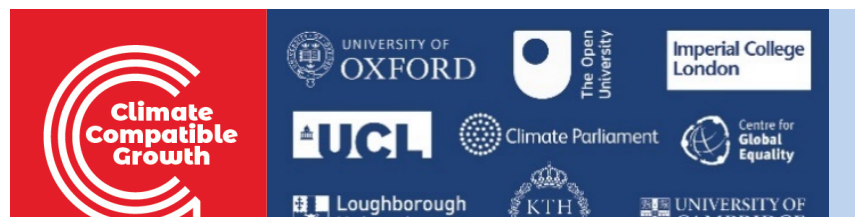 & 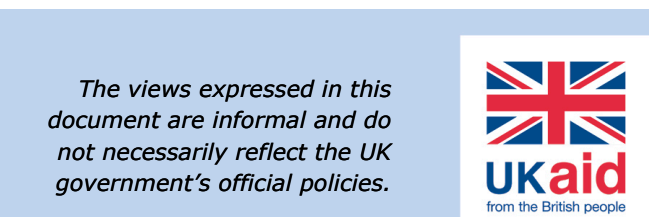 \\
\hline
\end{tabular}

\title{
Achieving a high share of non-hydro renewable integration in Brazil through wind power: regional growth and employment effects
}

\author{
Tiago Barbosa Diniz* and Lilia Caiado Couto
}

\section{Key Messages}

- Successful renewable energy policies increased installed wind power capacity in Brazil almost 20-fold from 2010 to 2020.

- $88 \%(15 \mathrm{GW})$ are concentrated in Brazil's poorest region, the Northeast, where those policies propel development and job creation.

- In the absence of renewable policies, we estimate that there would have been a GDP loss of $0.15 \%$ nationally and of $1.1 \%$ in the Northeast region, with negative impacts to labour market mostly over skilled jobs.

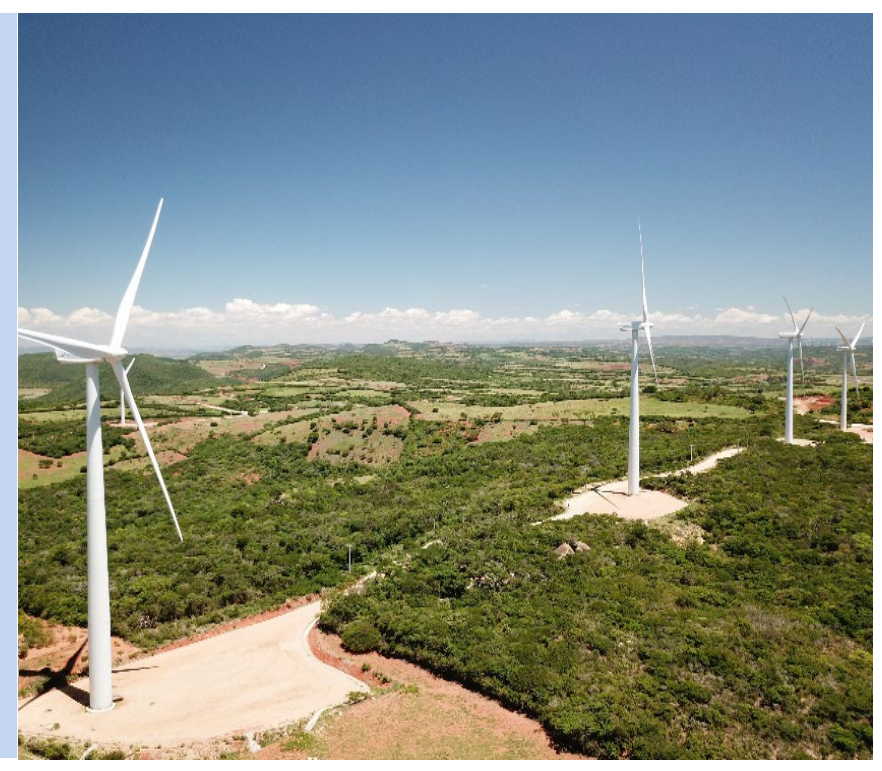

Wind Complex Pindaí I, State of Bahia, Brazil (Property of W Consult Ltd.)

\section{Introduction}

Brazil is a remarkably successful case of achieving a high share of wind energy integration to an interconnected power system in Low and MiddleIncome Countries (LMICs). A series of successful energy supply programmes and policies have been implemented since 2004 to promote alternative renewables, combined with strong renewable-oriented finance from the national development bank.

Thus, wind installed capacity increased almost 20-fold from $927 \mathrm{MW}$ in 2010 to $17.1 \mathrm{GW}$ in 2020 , reaching $10.0 \%$ of total procured power [1]. From this total, $88 \%(15 \mathrm{GW})$ are concentrated in Brazil's least developed region, the North-east, where development indicators are comparable to the Least Developed Countries (LDCs) and wind investment should create jobs and propel socio-economic development.

Furthermore, the National Interconnected System allows Northeast-based wind power to enhance Brazil's energy security, particularly after precipitation regime changes made hydropower highly generation unpredictable [2].

This research applies the interregional Computable General Equilibrium (CGE) model for Brazil, known as TERM-BR10, and assesses socio-economic impacts of successful wind policies from 2010 to 2019.

Our results suggest that both Brazil and the North-east region experience an increase in GDP and employment creation, mostly skilled jobs, relative to a no-policy case.

\section{Policy Background}

This success of wind power development in Brazil has been attained through renewable energy policies and programmes in place since 2004. In the latter, the Brazilian Federal government launched what is considered the main propeller of wind power: the "Incentive Programme for Alternative Sources of Electricity", known as PROINFA. Its first phase consisted of a guarantee from the government that at least $3.3 \mathrm{GW}$ of alternative renewable electricity -1.4 GW of which wind power would be procured in electricity auctions through price subsidies 
[3]. Once the $3.3 \mathrm{GW}$ had been procured, the second phase of the programme consisted of attaining a share of at least $10 \%$ of the electricity generation mix from alternative renewable sources over a twenty-year time span: a target that has already been reached, led by wind power. For both phases, the programme requires that at least $60 \%$ of components are sourced from local industries.

PROINFA has been considered a quite successful programme, particularly with regard to wind power [4]. In 2009, after having achieved a total of $602 \mathrm{MW}$ of wind installed capacity, the first specific auction for wind power procurement took place [5]. At the auction $1.8 \mathrm{GW}$ of capacity was procured to be installed by 2016. In 2010, the first Alternative Electricity Sources took place, in which around $2 \mathrm{GW}$ were procured [6].

Noticeably, Brazil is an outstanding case for renewable energy finance, as the national development bank (BNDES, from the acronym in Portuguese) was ranked fourth among the largest global renewable energy investors in 2014, with US $\$ 6.3$ billion in loans and shareholding, only behind the $\mathrm{KfW}$, the European Investment Bank, and the World Bank, all of which from high-income countries [7]. Indeed, BNDES has thrived in promoting energy security, integrating underdeveloped regions, and promoting smart growth [8].

These initiatives allowed wind power to gain scale in Brazil, including the development of a national plant-component industry, allowing its prices per MWh to decrease steeply to a point in which dedicated auctions were no longer needed and wind power price became competitive against traditional sources, namely large hydro and thermal power generation [9]. This whole institutional framework, both through the energy supply and the financial sides, thrived in creating the right incentives for the private sector, which accounts for the largest share of wind project shareholding [9].

In this briefing, we shed light into how the successful policies for increasing the share of wind power in Brazil have promoted climate-compatible growth. This holds true mostly to Brazil's North-east region.

\section{Economic Impacts}

In this analysis we have used the TERM-BR10 model [10] a dynamic recursive interregional Computable General Equilibrium (CGE) model for Brazil, with a detailed electricity feature to deal with substitution mechanisms between sources and transmission and distribution constraints, both at the regional level. For this simulation, we have aggregated it in 5 regions, ten occupation groups (labour by skill level), and four electricity generation sources. By applying these, we have assessed regional socio-economic impacts of power capacity expansion in Brazil from 2010 to 2019.

For this purpose, we modelled two electricity capacity expansion scenarios, namely:

- The baseline, in which we consider the electricity capacity expansion per source as observed, thus reflecting the policy effects, from 2010 to 2019, using data from the National Energy Balance [1].

- The no-policy scenario, in which we used planned capacity expansion rates from the official Decennial Expansion Plan published in 2010 for the period 20102019 [11].

Thus, our simulations compare the 10-year electricity expansion planned by the Brazilian government back in 2010, projecting much lower wind power expansion, to the actual wind power increase achieved up to 2019 owing to such policies.

Our preliminary results show that the expansion planned in 2010, a scenario where traditional technologies were predominant, would have yielded a much lower GDP and employment improvements to the Northeast region when compared to what actually happened (Table 1).

\begin{tabular}{lccc}
\hline & $\begin{array}{c}\text { Real } \\
\text { GDP }\end{array}$ & $\begin{array}{c}\text { Employ- } \\
\text { ment }\end{array}$ & $\begin{array}{c}\text { Real } \\
\text { Wage }\end{array}$ \\
\hline Brazil & $-0,18$ & 0,01 & $-0,85$ \\
\hline North & 0,13 & 0,06 & $-0,18$ \\
North-east & $-1,12$ & $-0,10$ & $-2,88$ \\
South-east & $-0,03$ & 0,03 & $-0,61$ \\
South & $-0,02$ & 0,02 & $-0,28$ \\
Centre & $-0,33$ & 0,01 & $-0,83$ \\
West & & & \\
\hline
\end{tabular}

Table 1: Macroeconomic results per region. Cumulative \% deviation from baseline.

Furthermore, if the scenario planned in 2010 had been observed, significantly less qualified jobs would have been created in the North-east region (Figure 1).

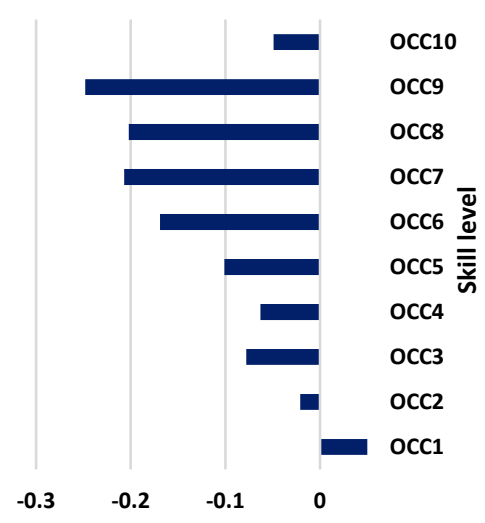

Figure 1: Northeast region: employment cumulative variation (\%) under a no-policy scenario per occupation group (OCC) 


\section{Recommendations}

- The Brazilian experience could be an important model of procurement, loan, and shareholding financial mechanisms and institutional incentives for those Low and MiddleIncome Countries which are in the initial stages of their renewable policies.
- We propose that such cobenefits are incorporated in future LMIC energy planning, which could promote regional equality through renewable energy expansion and be evaluated by existing methodologies, such as regional Computable General Equilibrium (CGE) models with electricity features.
- For Brazil, we recommend that future energy policy integrates regional development among its targets, besides energy security and the maintenance of the renewable profile of electricity mix, while the hydropower share decreases.

\section{References}

[1] EPE. BEN - Séries Históricas Completas. Empres Pesqui Energética 2021. https://www.epe.gov.br/pt/publicacoesdados-abertos/publicacoes/BEN-SeriesHistoricas-Completas (accessed July 5, 2021).

[2] Paim MA, Dalmarco AR, Yang $C H$, Salas $P$, Lindner $\mathrm{S}$, Mercure JF, et al. Evaluating regulatory strategies for mitigating hydrological risk in Brazil through diversification of its electricity mix. Energy Policy 2019;128:393-401. https://doi.org/10.1016/j.enpol.2018.12.06 4.

[3] Malagueta D, Szklo A, Borba BSMC, Soria R, Aragão R, Schaeffer R, et al. Assessing incentive policies for integrating centralized solar power generation in the Brazilian electric power system. Energy Policy 2013;59:198-212. https://doi.org/10.1016/j.enpol.2013.03.02 9.

[4] Eletrobras. Proinfa 2019. http://eletrobras.com/en/Paginas/Proinfa.as px (accessed March 12, 2019).
[5] Cunha G, Barrosos LA, Porrua F, Bezerra B. Fostering Wind Power through Auctions: the Brazilian Experience. In: Williams DL, editor. Int. Assoc. Energy Econ., 2012.

[6] Ringer NJ. Desafios do setor de energia eólica no Brasil: uma abordagem sistêmica. University of Sao Paulo, 2014.

[7] Grubb M, Ameli N, Drummond P, Bisaro S, Schuetz F. GREEN-WIN Green growth and win-win solutions for sustainable climate action 2020.

[8] Mazzucato M, Penna CCR. Beyond market failures: the market creating and shaping roles of state investment banks. J Econ Policy Reform 2016;19:305-26.

https://doi.org/10.1080/17487870.2016.12 16416.

[9] Diniz TB. Expansão da Indústria de Geração Eólica no Brasil. Planej e Políticas Públicas 2018:234-55.

[10] Diniz TB. Impactos econômicos e regionais dos investimentos em geração de energia elétrica no Brasil 2020:1-7.

[11] EPE. Plano Decenal de Expansão de Energia (PDE) 2019. Brasília-DF, Brazil: 2010.

\section{Notes}

Climate Compatible Growth (CCG) programme: CCG is funded by the UK's Foreign Development and Commonwealth Office (FCDO) to support investment in sustainable energy and transport systems to meet development priorities in the Global South.

\author{
Authors Information: \\ * Tiago Barbosa Diniz <tiagotbd@gmail.com>. Hydro- \\ electric Company of São Francisco - Eletrobras \\ CHESF. \\ Lilia Caiado Couto < lilia.couto@ucl.ac.uk>. Institute \\ for Sustainable Resources, University College London.
}




\section{Figures}

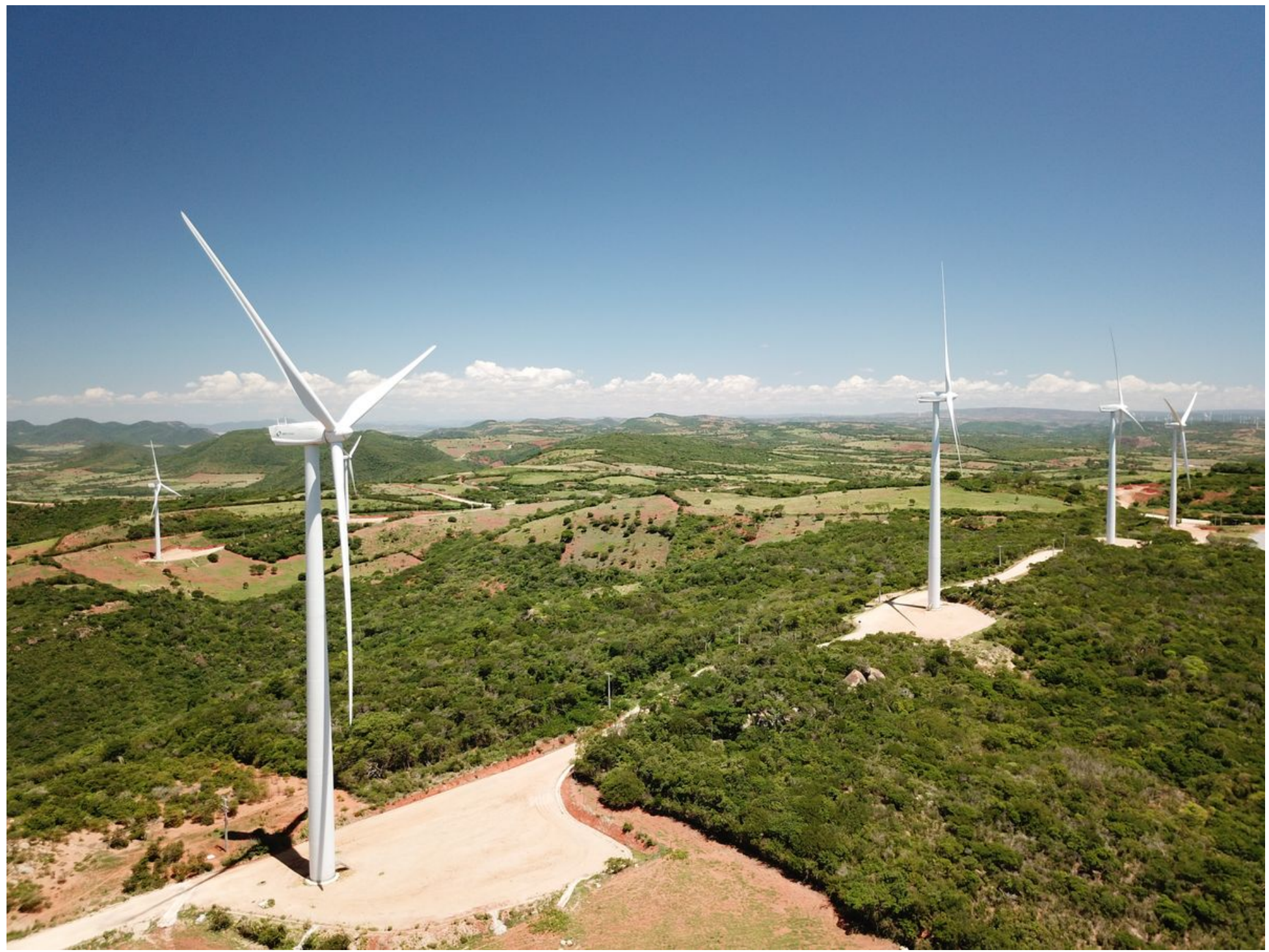

Figure 1

Wind Complex Pindaí I, State of Bahia, Brazil (Property of W Consult Ltd.) 